\title{
Retropupillary Iris-Claw Intraocular Lenses: A Literature Review
}

\author{
Mithun Thulasidas (DD \\ Cataract and Glaucoma services, Sankara \\ Eye Hospital, Coimbatore, Tamil Nadu, \\ 641035, India
}

\begin{abstract}
Retropupillary iris-claw intraocular lenses (ICIOLs) have been increasingly chosen by surgeons nowadays as a primary or secondary procedure of IOL implantation in eyes with insufficient capsular or zonular support. They have gained popularity due to their simple fast technique, favourable functional outcomes, and safety. The transition in the ICIOL fixation from prepupillary to a more biologically appropriate retropupillary position and change in the optic design from biconvex to convex-concave have provided better visual outcomes and improved safety. A peer-reviewed literature search was conducted in Medline (PubMed), Embase, and Cochrane Library using the keywords "retropupillary iris claw" and "iris claw". The search yielded 310 articles that were screened. Forty-three articles on retropupillary ICIOLs were finally found to be relevant and reviewed in full-text versions. The functional outcomes following retropupillary implantation of ICIOLs have been acceptable in eyes with no ocular co-morbidities otherwise. However, the indications for surgery may affect the outcomes. The major postoperative complications directly associated with ICIOLs include pupil ovalization and redislocation. Nevertheless, the rate of disenclavation depends on the experience and skill of the surgeon. This review is based on a literature review, and it focuses on the preoperative evaluation, surgical technique, postoperative outcomes, and associated complications. Prospective randomized trials with a larger sample size and longer follow-up are needed for comparison with other techniques of IOL fixation and confirmation of long-term safety profile.
\end{abstract}

Keywords: iris-claw, retropupillary iris-claw, posterior iris-claw, IOL dislocation

\section{Introduction}

Aphakia management as a consequence of complicated cataract surgery is difficult for the cataract surgeon. Insufficient posterior capsular or ciliary zonular support makes it unfeasible to implant a conventional posterior chamber intraocular lens (IOL).

Ophthalmologists preferred non-intervention for many decades, as secondary implants then had a greater risk of reduced final corrected distance visual acuity (CDVA) and complications. ${ }^{1}$ However, patients with unilateral aphakia presented with high hyperopia and/or high anisometropia, which were difficult to deal with by optical methods. Secondary IOL implantation, in a case of loss of capsular or zonular support, includes angle-supported anterior chamber IOL (ACIOL), scleralsupported (different surgical techniques) and iris-claw (prepupillary and retropupillary) IOLs. The preference and experience of the surgeon play a significant role in choosing one technique over the other.

IOL sizing is one of the major drawbacks of ACIOL. An IOL diameter suitable to the anterior chamber diameter is required to maintain the IOL in position and avoid
Correspondence: Mithun Thulasidas Cataract and Glaucoma services, Sankara Eye Hospital, Sathy Road,

Sivanandapuram, Coimbatore, Tamil Nadu, 641035, India

Email mithun.thulasidas@gmail.com 
complications. Complications associated with incorrect IOL sizing are common due to the limited availability of different diameters. A small-diameter IOL causes rotation and dislocation, increasing the risk of corneal endothelial damage and anterior chamber angle damage. A large-diameter IOL can lead to the formation of peripheral anterior synechiae, increased intraocular pressure (IOP), and glaucoma due to excess pressure caused on the iris root. ${ }^{2-4}$

Scleral fixation of posterior chamber IOL implantation has major advantages like the more biological location in the eye closer to the plane of the crystalline lens away from the cornea, which decreases the risk of corneal endothelial damage. ${ }^{5,6}$ However, severe complications may occur due to transscleral sutures, like suture erosion, haptic extrusion, retinal detachment, suprachoroidal haemorrhage, and endophthalmitis. ${ }^{7-9}$

The iris-claw IOL (ICIOL) attached to the anterior iris was introduced by Worst in $1972 .{ }^{10} \mathrm{He}$ developed a surgical technique to correct aphakia in the absence of capsular or zonular support without damaging the angle of the anterior chamber. However, a major complication associated with it, was the corneal endothelium damage, especially in patients with narrow anterior chambers and in corneal transplantation. ${ }^{11}$ Brasse and Neuhann modified this technique by fixing the lens to the posterior surface of the iris, thereby preserving the corneal endothelial cells, with the A-constant altered accordingly to $117.0{ }^{12}$ Secondary implantation of ICIOL has been the preferred procedure in cases where the iris support is adequate. ${ }^{1}$ Complications associated with the size of the IOL, like damage to the iris root and angle, are prevented, as it is fixed to the mid-periphery of the iris. The distinctive enclavation technique allows IOL centration on the pupillary axis, which is vital in eyes with decentred pupils. ${ }^{13}$ Although ICIOL is not United States Food and Drug Administration (FDA) approved at present for aphakia, it has been used widely outside of the United States considering its effective outcomes and safety profile.

This review provides a brief overview of retropupillary ICIOLs along with the preoperative evaluation, intraoperative approach, postoperative outcomes, and possible complications.

\section{Literature Search and Methods}

The literature search was performed in Medline (PubMed), Embase, and Cochrane Library using "retropupillary iris claw" and "iris claw" as keywords. The relevant references cited in those articles were also searched.
"Retropupillary iris claw" and "iris claw" keywords generated 76 and 310 articles in Medline (PubMed), respectively. Thirteen articles on retropupillary ICIOLs that were not identified with "retropupillary iris claw" keyword were identified with "iris claw" keyword. Seven review articles on retropupillary ICIOLs, including one meta-analysis and four non-English reviews, were identified. Embase and Cochrane Library searches did not reveal any additional pertinent articles. A total of 310 publications were independently screened, and those which are case reports/correspondence, articles with $\leq 10$ eyes, incomplete data, and/ or involving phakic/prepupillary ICIOLs solely were excluded. Forty-three original articles on retropupillary ICIOL were exclusively reviewed in full-text versions. Of the 43 articles, 11 were prospective (4 randomized and comparative), and 32 were retrospective studies (10 comparative). Articles in non-English language were translated to English language using "Google Translate".

\section{Preoperative Evaluation}

It is essential to take a complete history from the patients, especially past ocular and medical history, to explore the potential possibilities of their ocular future. The patient should undergo a thorough comprehensive ocular examination to rule out any ocular co-morbidity that may interfere with the postoperative outcomes. Table 1 shows the different ICIOLs whose outcomes have been studied in the literature.

A retropupillary ICIOL is indicated in cases with insufficient capsular and/or zonular support, where implanting a standard posterior chamber IOL is futile. This usually happens secondary to complicated cataract surgery with a large posterior capsular rent or extended capsulorhexis where IOL implantation in the ciliary sulcus is impossible, ocular trauma, ectopia lentis and pseudoexfoliation syndrome. Other indications for ICIOL widely reported in the literature are late in-thebag dislocation of posterior chamber IOL after years of initial surgery and primary IOL opacification. ${ }^{14-56}$ Retropupillary ICIOL implantation can also be combined with keratoplasty procedures. ${ }^{18,33,36,44,45,54,56}$ However, a careful assessment of the iris and the pupil place is essential.

The iris must have sufficient support for the implantation of retropupillary ICIOL. However, ICIOL can be implanted in cases with small iris defects and localized atrophic areas, provided such sites are avoided. ${ }^{36,57}$ To achieve an optimal functional outcome, the pupil should preferably be of regular size and shape. Although ICIOL can be used in cases of dilated pupils secondary to 
Table I Different ICIOLs Whose Outcomes Have Been Studied in the Literature

\begin{tabular}{|l|l|l|l|l|}
\hline ICIOL & Material & Optic Design & $\begin{array}{l}\text { IOL Diameter } \\
(\mathbf{m m})\end{array}$ & $\begin{array}{l}\text { A Constant } \\
\text { (Retropupillary) }\end{array}$ \\
\hline $\begin{array}{l}\text { Verisyse (VRSA54, Abbott Laboratories, Inc., } \\
\text { Abbott Park, IL, USA) }\end{array}$ & PMMA & $\begin{array}{l}\text { Biconvex/convex-concave/ } \\
\text { plano-convex }\end{array}$ & 8.50 & II6.9 (SRK/T) \\
\hline $\begin{array}{l}\text { Artisan Aphakia (Ophtec, Groningen, The } \\
\text { Netherlands) }\end{array}$ & PMMA & $\begin{array}{l}\text { Biconvex/convex-concave/ } \\
\text { plano-convex }\end{array}$ & 8.50 & $116.9($ SRK/T) \\
\hline Excelens (Excel Optics Pvt. Ltd., Chennai, India) & PMMA & Biconvex/plano-convex & $7.25 / 8.00 / 9.00$ & $117.2($ SRK/T) \\
\hline $\begin{array}{l}\text { Freedom (Freedom Ophthalmic Pvt. Ltd., Hosur, } \\
\text { India) }\end{array}$ & PMMA & Biconvex/convex-concave & $7.20 / 8.50$ & $117.4($ SRK/T) \\
\hline Optima (Rainbow Meditech LLC, Chennai, India) & PMMA & Convex-concave & $7.25 / 8.00 / 9.00$ & $117.2($ SRK/T) \\
\hline OV lens (Care Group, India) & PMMA & Biconvex & 8.50 & $117.2($ SRK/T) \\
\hline
\end{tabular}

Abbreviations: ICIOL, Iris-claw intraocular lens; PMMA, polymethyl methacrylate; SRK/T, Sanders-Retzlaff-Kraff/Theoretical.

traumatic sphincter damage, large pupil size may lead to optical disturbances from the edges of the optic and the haptics, and safe enclavation of the haptics may be practically challenging. Nevertheless, retropupillary ICIOL implantation can be combined with pupilloplasty in cases with traumatic mydriasis. ${ }^{58}$ On the other hand, in extreme miosis cases, ICIOL should be placed anterior to the iris to prevent sphincter trauma during implantation. ${ }^{57}$

Contraindications for retropupillary ICIOL implantation include gross iris abnormalities like aniridia, diffuse iris atrophy, rubeosis iridis, profound iridodonesis (which may cause trembling vision), and active uveitis. ${ }^{16,24,26,36}$

The medical history of the patient, mainly regarding the consumption of anticoagulant and antiplatelet drugs, is important. ICIOL implantation is commonly performed under a peribulbar or retrobulbar block, and hence, discontinuing the anticoagulants and/or antiplatelet therapy 3-5 days before the surgery might avoid the risk of severe bleeding. However, a cardiologist opinion must be taken regarding temporary discontinuation of the medications as risking minor bleeding is always preferable to risking the patient's cardiovascular condition.

A complete peripheral retinal evaluation using an indirect ophthalmoscope to rule out any pre-existing retinal tear or hole is mandatory for cases of secondary ICIOL implantation. Also, specular microscopy for corneal endothelial status, and macular optical coherence tomography (OCT) for underlying retinal conditions, in addition to a good keratometry and biometry for IOL power calculation, should be performed as a routine for cases of secondary ICIOL implantation.

\section{Optic Design of ICIOL}

The first ICIOL (Artisan model 205) for aphakia correction had a plano-convex configuration, which was launched in the 1970s. However, the plano-convex design caused significant corneal endothelial cell loss (ECL), resulting in bullous keratopathy. ${ }^{59,60}$ The ICIOL was then redesigned to a biconvex configuration, which warrants the need for a peripheral iridectomy in all cases of ICIOL implantation to prevent pupillary block and secondary glaucoma. ${ }^{46,48,51,53}$ The optic architecture was later updated to a convex-concave vaulted design in the 1990s. Both biconvex and convex-concave designs are currently widely used. Nevertheless, a convex-concave design has a better safety profile, and a peripheral iridectomy is not required with this design. ${ }^{17,24,26,28,36,54}$

\section{Intraoperative Approach}

Peribulbar, subtenon, or retrobulbar anaesthesia is preferred while implanting ICIOL, as the surgical manoeuvres, including iris-touch and enclavation, may induce pain. ${ }^{16,17,21,24,26,36}$ The pupil should neither be dilated nor constricted. Mohr et al suggested a pupil size of 4-5 mm, optimal for secondary ICIOL implantation. ${ }^{61}$ However, in cases of primary implantation of ICIOL or exchange of IOL, which require dilated pupil, a constrictive agent like carbachol or pilocarpine must be injected intracamerally before enclavating the haptics of ICIOL. ${ }^{17,21,24,26,28,36}$ The size of the pupil should be assessed before injecting the constricting drug, and one should proceed cautiously to avoid sphincter trauma while enclavating the haptics. 
Different authors have reported using a corneal incision or a scleral tunnel incision at the 12 o'clock position for implanting ICIOL. ${ }^{16,17,21,24,26,36}$ However, the size of the ICIOL demands a $5.4 \mathrm{~mm}$ incision, which can be considered as one of the drawbacks of ICIOL. Hence, making a sclero-corneal tunnel is preferable as it reduces the surgically induced astigmatism (SIA) and chances of wound leakage and endophthalmitis. ${ }^{62,63}$ In glaucoma patients, the superior site should be better reserved for trabeculectomy and other filtering surgeries that may become obligatory in the future. Fashioning a scleral tunnel requires surgical skills and experience, though it is easier in the hands of those who practice manual small incision cataract surgery (SICS). The tunnel should be one-third to half of the width of the thickness of the sclera extending $1.5 \mathrm{~mm}$ into the cornea. A thin flap tends to tear or gives way to a button-hole formation. If the button-hole is on one side, the other end is dissected further to continue with the same incision. If the button-hole is in the centre, the original site is abandoned, and another site is chosen, or dissection is carried out at a deeper plane in the same location. A thick deep flap may lead to premature entry, resulting in prolapse of the uveal tissue and increased bleeding into the anterior chamber. A different site should be chosen for scleral incision then, and proper closure of the premature tunnel using multiple 10-0 nylon sutures should be done. On the other hand, a corneal incision can be preferred in cases of thin, brittle conjunctiva or marked conjunctiva-episcleral adherence. ${ }^{57}$

The majority of the surgeons prefer to make two paracenteses at 3 o' and 9 o'clock, with the main wound at 12 o'clock position. ${ }^{36}$ Anterior or posterior vitrectomy has to be done whenever required. Remnants of the capsule must be removed before implanting ICIOL as postoperative capsular fibrosis may cause IOL instability. ${ }^{21,36,40}$ After injecting viscoelastic, the ICIOL, with its concavity oriented anteriorly, is inserted into the anterior chamber by forceps, turned to the horizontal position and centred on the pupil. A specific iris-claw forceps for fixating the ICIOL in the anterior chamber is also available. After injecting a small amount of viscoelastic on the peripheral iris, holding the middle of the optic with the forceps, one haptic should be tilted down and pushed under the iris with gentle manipulation. Before enclavating the haptics, the ICIOL should be maintained in the correct position with the optic centred in the pupil. A sinskey hook can be inserted through the paracentesis to aid in the manoeuvering. Tilting the haptics will produce an indentation on the iris. The iris must be enclavated into the haptic claw with a gentle push with the sinskey hook. Less pressure should be used while enclavation as extrusion of the claw may occur with too much pressure. Moreover, the excessive iris tissue enclavation may lead to ovalization of the pupil. Finally, the two dimples in the iris due to haptic enclavation should be identified to ensure the appropriate fixation of the ICIOL. A peripheral iridectomy is not mandatory with a convex-concave vaulted design ICIOL, as mentioned in various studies. ${ }^{17,24,26,28,36,54}$ However, if the ICIOL used was a biconvex design, a peripheral iridectomy is a must to prevent pupillary block. ${ }^{46,48,51,53}$

Most of the studies have reported standard medication following ICIOL implantation, which includes topical steroids and antibiotics. ${ }^{16,28,54}$ Topical non-steroidal antiinflammatory drugs (NSAIDs) can be used postoperatively to reduce the risk of CME. Nevertheless, no studies have reported using topical NSAIDs prophylactically in cases of ICIOL implantation to decrease the incidence of CME.

\section{Postoperative Outcomes \\ Visual Acuity}

Table 2 shows the overview of visual outcomes reported in the literature after ICIOL implantation. ${ }^{14-56}$ The functional outcomes following retropupillary ICIOL implantation have been acceptable in eyes with no other ocular comorbidities. However, the indications for ICIOL implantation will affect the outcomes. The postoperative mean logarithm of the minimum angle of resolution (logMAR) in different studies varies from 0.09 to 1.0 , depending on the indication and status of the eye before surgery. ${ }^{14-56}$ In a prospective, randomized clinical trial comparing retropupillary ICIOL implantation $(\mathrm{n}=30)$ with IOL repositioning to the sclera $(\mathrm{n}=33)$ in late in-the-bag IOL dislocation, Dalby et al found a mean CDVA of 0.22 and $0.20 \log$ MAR, in the ICIOL and scleral suturing IOL groups, respectively, at 2 years follow-up. ${ }^{14}$ Kristianslund et al compared the efficacy of retropupillary ICIOL fixation $(n=42)$ and IOL repositioning by scleral suturing (n $=43$ ) in patients with late in-the-bag IOL dislocation. A CDVA of $20 / 40$ or better was observed in $62 \%$ and $61 \%$ of the patients in ICIOL and repositioning groups, respectively, at 6 months follow-up. ${ }^{16}$ In a retrospective study by Toro et al comparing the prepupillary $(\mathrm{n}=87)$ and retropupillary $(n=93)$ ICIOLs with an average follow-up of 5 years, no significant differences in visual outcomes were observed. $^{28}$ Another retrospective 
Table 2 Overview of Visual Outcomes Reported in the Literature After Retropupillary ICIOL Implantation

\begin{tabular}{|c|c|c|c|c|c|c|}
\hline \multirow[t]{2}{*}{ ICIOL } & \multirow[t]{2}{*}{ Authors } & \multirow[t]{2}{*}{ Study Design } & \multirow{2}{*}{$\begin{array}{l}\text { Sample } \\
\text { Size }\end{array}$} & \multirow{2}{*}{$\begin{array}{l}\text { Mean or } \\
\text { Median } \\
\text { Follow-Up } \\
\text { (Months) }\end{array}$} & \multicolumn{2}{|l|}{ CDVA } \\
\hline & & & & & $\begin{array}{l}\text { Mean/ Median } \\
\text { (logMAR/ } \\
\text { Decimal) }\end{array}$ & $\begin{array}{l}\geq 20 / 40 \\
\text { (\%) }\end{array}$ \\
\hline $\begin{array}{l}\text { Verisyse (VRSA54, } \\
\text { Abbott Laboratories, } \\
\text { Inc., Abbott Park, IL, } \\
\text { USA) }\end{array}$ & 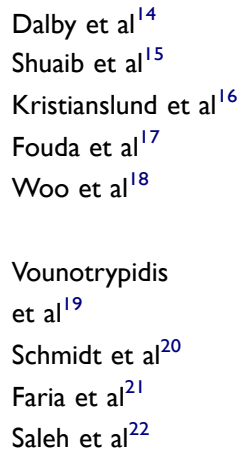 & $\begin{array}{l}\text { Prospective randomized comparative } \\
\text { Prospective randomized comparative } \\
\text { Prospective randomized comparative } \\
\text { Prospective } \\
\text { Retrospective comparative } \\
\text { Retrospective comparative } \\
\text { Retrospective case series } \\
\text { Retrospective case series } \\
\text { Retrospective case series }\end{array}$ & $\begin{array}{l}33 \\
15 \\
42 \\
17 \\
25 \\
39 \\
19 \\
66 \\
18\end{array}$ & $\begin{array}{l}24 \\
6 \\
6 \\
6 \\
46.8 \\
17 \\
52 \text { days } \\
23 \\
14\end{array}$ & $\begin{array}{l}0.22 \pm 0.30^{\mathrm{a}} \\
0.40 \pm 0.23^{\mathrm{b}} \\
0.35 \pm 0.54^{\mathrm{a}} \\
0.9 \pm 0.07^{\mathrm{b}} \\
- \\
0.42 \pm 0.48^{\mathrm{a}} \\
0.36 \pm 0.39^{\mathrm{a}} \\
0.35 \pm 0.40^{\mathrm{a}} \\
0.32 \pm 0.47^{\mathrm{a}}\end{array}$ & $\begin{array}{l}76 \\
- \\
62 \\
- \\
21(36 \\
\text { months) } \\
- \\
- \\
- \\
67\end{array}$ \\
\hline $\begin{array}{l}\text { Artisan Aphakia } \\
\text { (Ophtec, Groningen, } \\
\text { The Netherlands) }\end{array}$ & 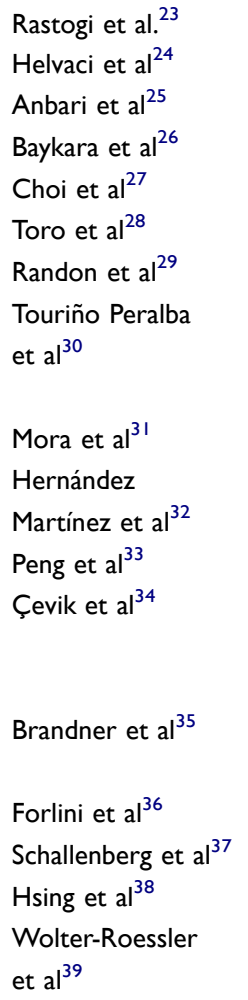 & $\begin{array}{l}\text { Prospective } \\
\text { Prospective randomized comparative } \\
\text { Prospective } \\
\text { Prospective } \\
\text { Retrospective case series } \\
\text { Retrospective comparative } \\
\text { Retrospective case series } \\
\text { Retrospective comparative } \\
\text { Retrospective comparative } \\
\text { Retrospective comparative } \\
\text { Retrospective } \\
\text { Retrospective } \\
\text { Retrospective case series } \\
\text { Retrospective } \\
\text { Retrospective } \\
\text { Retrospective } \\
\text { Retrospective }\end{array}$ & $\begin{array}{l}32 \\
44 \\
29 \\
30 \\
\\
15 \\
320 \\
31 \\
34 \\
48\end{array}$ & $\begin{array}{l}6 \\
6 \\
24 \\
9 \\
24 \\
60 \\
29 \\
12 \text { (median) } \\
12 \\
33 \\
6 \\
38 \\
14.9 \\
63.6 \\
25.2 \\
21.4 \\
14\end{array}$ & $\begin{array}{l}0.35 \pm 0.15^{\mathrm{a}} \\
0.50 \pm 0.23^{\mathrm{a}} \\
0.13 \pm 0.21^{\mathrm{a}} \\
- \\
0.22 \pm 0.46^{\mathrm{a}} \\
0.13 \pm 0.15^{\mathrm{a}} \\
0.17 \pm 0.50^{\mathrm{a}} \\
65 \text { ETDRS } \\
\text { letters }\left(0.4^{\mathrm{a}}\right) \\
(\text { median) } \\
0.37 \pm 0.50^{\mathrm{a}} \\
0.09 \pm 0.32^{\mathrm{a}} \\
- \\
0.39 \pm 0.46 / \\
0.64 \pm 0.77^{\mathrm{a}}(I \\
\text { month) } \\
0.25 \pm 0.21^{\mathrm{a}} \\
(\text { median) } \\
0.6 / 0.3 / 0.6^{\mathrm{a}} \\
0.64 \pm 0.62^{\mathrm{a}} \\
- \\
0.2^{\mathrm{a}}(\text { median})\end{array}$ & $\begin{array}{l}71 \\
- \\
- \\
88 \\
- \\
- \\
- \\
- \\
73 \\
- \\
66 \\
60 \\
\\
- \\
- \\
- \\
-\end{array}$ \\
\hline Artisan/ Verisyse & $\begin{array}{l}\text { Choragiewicz et al }{ }^{40} \\
\text { Gonnermann et } \mathrm{al}^{4 !} \\
\text { Gonnermann et } \mathrm{al}^{42} \\
\text { Gonnermann et } \mathrm{al}^{43} \\
\text { Gonnermann et } \mathrm{al}^{44} \\
\text { Rüfer et al }{ }^{45}\end{array}$ & $\begin{array}{l}\text { Retrospective case series } \\
\text { Retrospective case series } \\
\text { Retrospective } \\
\text { Retrospective } \\
\text { Retrospective } \\
\text { Retrospective comparative }\end{array}$ & $\begin{array}{l}47 \\
137 \\
62 \\
13 \\
23 \\
22\end{array}$ & $\begin{array}{l}15.9 \\
5 \\
34 \\
37 \\
18 \\
17\end{array}$ & $\begin{array}{l}0.46 \pm 0.27^{\mathrm{b}} \\
0.38 \pm 0.31^{\mathrm{a}} \\
0.24 \pm 0.45^{\mathrm{a}} \\
0.24 \pm 0.36^{\mathrm{a}} \\
1.0 \pm 0.46^{\mathrm{a}} \\
0.53 \pm 0.43^{\mathrm{a}}(10 \\
\text { months }) / 1.01 \pm \\
0.38^{\mathrm{a}}(23 \\
\text { months })\end{array}$ & $\begin{array}{l}- \\
- \\
77 \\
85 \\
- \\
-\end{array}$ \\
\hline
\end{tabular}

(Continued) 
Table 2 (Continued).

\begin{tabular}{|c|c|c|c|c|c|c|}
\hline \multirow[t]{2}{*}{ ICIOL } & \multirow[t]{2}{*}{ Authors } & \multirow[t]{2}{*}{ Study Design } & \multirow{2}{*}{$\begin{array}{l}\text { Sample } \\
\text { Size }\end{array}$} & \multirow{2}{*}{$\begin{array}{l}\text { Mean or } \\
\text { Median } \\
\text { Follow-Up } \\
\text { (Months) }\end{array}$} & \multicolumn{2}{|l|}{ CDVA } \\
\hline & & & & & $\begin{array}{l}\text { Mean/ Median } \\
\text { (logMAR/ } \\
\text { Decimal) }\end{array}$ & $\begin{array}{l}\geq 20 / 40 \\
\text { (\%) }\end{array}$ \\
\hline $\begin{array}{l}\text { Excelens (Excel } \\
\text { Optics Pvt. Ltd., } \\
\text { Chennai, India) }\end{array}$ & $\begin{array}{l}\text { Jare et } \mathrm{al}^{46} \\
\text { Rao et } \mathrm{al}^{47} \\
\text { Mansoori et } \mathrm{al}^{48} \\
\text { Kelkar et } \mathrm{al}^{49} \\
\text { Kelkar et } \mathrm{al}^{50} \\
\text { Jayamadhury et } \mathrm{al}^{51} \\
\text { Kavitha et } \mathrm{al}^{52} \\
\text { Patil et } \mathrm{al}^{53}\end{array}$ & $\begin{array}{l}\text { Prospective } \\
\text { Prospective } \\
\text { Retrospective } \\
\text { Retrospective comparative } \\
\text { Retrospective } \\
\text { Retrospective } \\
\text { Retrospective comparative } \\
\text { Retrospective case series }\end{array}$ & $\begin{array}{l}108 \\
30 \\
122 \\
90 \\
104 \\
61 \\
25 \\
15\end{array}$ & $\begin{array}{l}6 \\
6 \\
7.48 \\
12 \\
12 \\
12 \\
16 \\
12\end{array}$ & $\begin{array}{l}0.25^{\mathrm{a}} \\
- \\
0.5 \pm 0.42^{\mathrm{a}} \\
0.36 \pm 0.32^{\mathrm{a}} \\
(\mathrm{UDVA}) \\
0.36 \pm 0.32^{\mathrm{a}} \\
0.27 \pm 0.46^{\mathrm{a}} \\
- \\
-\end{array}$ & $\begin{array}{l}97 \\
80 \\
- \\
- \\
71 \\
- \\
64 \\
40\end{array}$ \\
\hline $\begin{array}{l}\text { Freedom (Freedom } \\
\text { Ophthalmic Pvt. Ltd., } \\
\text { Hosur, India) }\end{array}$ & Sumitha et $\mathrm{a}^{54}$ & Prospective & 36 & 3 & - & $\begin{array}{l}81(\geq \\
20 / 60)\end{array}$ \\
\hline $\begin{array}{l}\text { Optima (Rainbow } \\
\text { Meditech LLC, } \\
\text { Chennai, India) }\end{array}$ & Madhivanan et al ${ }^{55}$ & Retrospective comparative & 48 & 12 & $0.40 \pm 0.40^{\mathrm{a}}$ & 71 \\
\hline $\begin{array}{l}\text { OV lens (Care Group, } \\
\text { India) }\end{array}$ & Ganesh et $\mathrm{al}^{56}$ & Retrospective & 100 & 13 & $0.38^{\mathrm{a}}$ & - \\
\hline
\end{tabular}

Notes: ${ }^{a} \log M A R,{ }^{b}$ Decimal notation.

Abbreviations: ICIOL, iris-claw intraocular lens; CDVA, corrected distance visual acuity; logMAR, logarithm of the minimum angle of resolution; ETDRS, Early Treatment Diabetic Retinopathy Study; UDVA, uncorrected distance visual acuity.

comparative study by Mora et al showed comparable improvements in CDVA at the end of 1 year after surgery (final CDVA: $0.34 \pm 0.45$ versus $0.37 \pm 0.50 \log$ MAR) in the anterior $(\mathrm{n}=28)$ and retropupillary $(\mathrm{n}=32)$ placement groups, respectively. ${ }^{31}$ Hernández Martínez et al in their retrospective case series compared the the incision type (corneal versus scleral tunnel) and lens position (prepupillary versus retropupillary) in aphakic eyes without capsular support. They found that implantation of ICIOL in the retropupillary position and through a scleral tunnel incision provided better refractive results than other techniques. ${ }^{32}$ Even in cases of retropupillary ICIOL combined with keratoplasty and vitrectomy $(n=57)$, Forlini et al found a mean $\log$ MAR of 0.6 at the end of 5 years follow-up. ${ }^{36}$

The A-constants of different ICIOLs are given by the manufacturers for the Sanders-Retzlaff-Kraff/Theoretical (SRK/T) formula (Table 1). As ICIOLs are mainly used in aphakic eyes post-complicated surgery and eyes with dislocated IOLs or ectopia lentis, newer IOL formulas are unreasonable. The majority of the studies in the literature have used the SRK/T formula. ${ }^{16,21,26,28,31,36}$ In approximately $80 \%$ of the studies using the SRK/T formula, more than $50 \%$ had attained a spherical equivalent $\leq 1.0$ diopter (D) using different A-constants (116.7-117.5). ${ }^{16,26,31}$ However, a few studies have not disclosed the IOL formula or A-constant used. ${ }^{45}$ Choragiewicz et al have used the Haigis formula, Schallenberg et al have used the SRKII formula, and Vounotrypidis et al have used the Haigis formula for eyes with axial length $\geq 22 \mathrm{~mm}$, the Hoffer-Q for eyes with axial length $<22 \mathrm{~mm}$, and the SRK/T for aphakic and pseudophakic eyes. ${ }^{19,37,40}$ Nevertheless, the spherical equivalent $\leq 1.0 \mathrm{D}$ was observed in studies using multiple formulas too.

The mean prediction error in multiple studies varied from -2.4 to +0.29 D. ${ }^{16,19,21,26,36,40}$ This variation in prediction error might be due to the spherical equivalent analysis in accordance with residual or absolute error. Furthermore, refractive status may also rely upon the indication for surgery, particularly when combined with keratoplasty. ${ }^{36}$ Given the inadequate refractive outcomes and varied results reported, more studies with a large sample size are required, detailing the formulas and A-constants used, to determine a more appropriate IOL formula and A-constant for ICIOLs to achieve better refractive outcomes. 


\section{Complications}

Table 3 shows the overview of major complications reported in the literature after ICIOL implantation. ${ }^{14-56,64}$

\section{Pupil Ovalization}

Horizontal ovalization of the pupil in the early postoperative phase is observed in a range of $0 \%$ $44 \%{ }^{15,17,20,21,23-26,28,30,36-38,40-44,48-52,54-56}$ This pupil ovalization is mostly temporary and usually pupil dilation is not affected. Toro et al found a temporary $(<1$ week) pupil ovalization in only $2(2 \%)$ patients. They have applied light diathermy on the anterior surface of the iris for tissue contraction wherever the pupil was minimally distorted. ${ }^{28}$ Forlini et al observed ovalization of the pupil in $5 \%$ of the patients, all of whom had previously undergone iris reconstruction. ${ }^{36}$ Permanent ovalization might occur due to haptic enclavation near the margin of the pupil instead of the desired mid-peripheral area or if the enclavation of the haptics is performed tightly or asymmetrically. However, no intervention is required for pupillary distortion in most cases. With surgical experience and skill, achieving a round pupil with ICIOLs is definitely possible.

\section{Elevated IOP}

Initially, the use of prepupillary ICIOLs could lead to an increase in IOP and exacerbate glaucoma. ${ }^{65-67}$ A peripheral iridectomy was mandatory in earlier days to prevent any possibility of pupillary block. Nevertheless, the shift in the placement of ICIOLs to a more physiological retropupillary position and change in the optic design from biconvex to convex-concave have reduced the possibility of raised postoperative IOP. A pupillary block does not happen with a convex-concave vaulted design, and a peripheral iridectomy is not needed nowadays for retropupillary ICIOL implantation. ${ }^{17,24,26,28,36,54}$ In fact, the majority of the studies have shown only a mild-moderate increase in IOP in otherwise non-glaucomatous eyes, which is usually temporary and responds well to conservative treatment. However, studies have shown increased postoperative IOP at a frequency of up to $31 \%{ }^{14-18,20,21,23-28,30,31,33-52,54-56}$ This rise in IOP could be due to the postoperative inflammation and retained viscoelastic in the early postoperative period. ${ }^{16-18,21,26-28,54,55}$ Dalby et al and Kristianslund et al found no significant differences in the rate of glaucoma or increased IOP in patients who underwent IOL exchange for retropupillary ICIOLs compared with repositioning of the IOL in late in-the-bag IOL dislocation. ${ }^{14,16}$ Faria et al observed elevated IOP in $12(18 \%)$ eyes, all of which were medically managed. They did not perform peripheral iridectomies as no case of pupillary block was found. ${ }^{21}$ Choi et al stated that the IOP elevation in their study might be due to inflammation caused by vitrectomy rather than the ICIOL itself. ${ }^{27}$ Forlini et al reported no cases of pupillary block and attributed it to the vaulting design of the ICIOL and the appropriate space between the optic of the ICIOL and the posterior surface of the iris. ${ }^{36}$ Kelkar et al, in their retrospective comparative study, experienced a transient rise of IOP more in eyes with scleral-fixated IOL $(17 \%)$ than ICIOL $(8 \%)$, which was managed with topical therapy. ${ }^{49}$ Nevertheless, Madhivanan et al found that eyes with ICIOL $(10 \%)$ experienced greater transient IOP spikes due to iritis than eyes with scleral-fixated IOL $(0 \%){ }^{55}$

\section{ECL}

The possibility of ECL is lower with retropupillary ICIOL than anteriorly placed ICIOL and ACIOL due to the position of the IOL away from the corneal endothelium in the former. However, complicated cataract surgery, especially in cases of zonular dialysis (pseudoexfoliation), vitreous loss, and hard cataract, may cause a much higher ECL than an uneventful surgery. Also, in cases combined with multiple techniques like keratoplasty, iridoplasty and pupilloplasty, the ECL may be comparatively high. ${ }^{25,33,44}$ The risk of a mechanical injury to the endothelium due to the contact between the endothelium and the instruments or the IOL during the surgery can be reduced by using a copious amount of dispersive viscoelastic substance. ${ }^{68}$ Studies on retropupillary ICIOL have shown a considerable variation in ECL ranging from 3\%$43 \%{ }^{14-16,23,25,27,28,30-33,36,42-44,46,47,49-51,56}$ Dalby et al, in a prospective comparative clinical trial, observed no significant difference in ECL following ICIOL implantation (15\%) and IOL repositioning (18\%) for late in-the-bag IOL dislocation at the end of 2 years. ${ }^{64}$ In contrast, Kristianslund et al reported a significant postoperative ECL of $10 \%$ in the ICIOL group and a non-significant postoperative ECL of $3 \%$ in the repositioning group. Nevertheless, they mentioned that the ECL comparison in their study was limited by missing data in both groups. ${ }^{16}$ Baykara et al suggested that ICIOL implantation through a scleral tunnel incision causes less endothelial damage than through a clear corneal incision. ${ }^{26}$ Hernández Martínez et al found that the ECL was lower in the retropupillary group (4\%) than in the prepupillary group (14\%) 
Table 3 Overview of Major Complications Reported in the Literature After Retropupillary ICIOL Implantation

\begin{tabular}{|c|c|c|c|c|c|c|c|c|c|}
\hline ICIOL & Authors & $\begin{array}{l}\text { Sample } \\
\text { Size }\end{array}$ & $\begin{array}{l}\text { Mean or } \\
\text { Median } \\
\text { Follow-Up } \\
\text { (Months) }\end{array}$ & $\begin{array}{l}\text { Pupil } \\
\text { Ovalization } \\
\text { (\%) }\end{array}$ & $\begin{array}{l}\text { Raised } \\
\text { IOP } \\
(\%)\end{array}$ & ECL (\%) & $\begin{array}{l}\text { CME } \\
\text { (\%) }\end{array}$ & $\begin{array}{l}\text { IOL } \\
\text { Disenclavation/ } \\
\text { Dislocation (\%) }\end{array}$ & $\begin{array}{l}\text { RD } \\
\text { (\%) }\end{array}$ \\
\hline $\begin{array}{l}\text { Verisyse } \\
\text { (VRSA54, } \\
\text { Abbott } \\
\text { Laboratories, } \\
\text { Inc., Abbott } \\
\text { Park, IL, USA) }\end{array}$ & 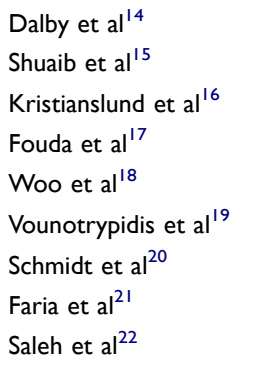 & $\begin{array}{l}33 \\
15 \\
42 \\
17 \\
25 \\
39 \\
19 \\
66 \\
18\end{array}$ & $\begin{array}{l}24 \\
6 \\
6 \\
6 \\
46.8 \\
17 \\
52 \text { days } \\
23 \\
14\end{array}$ & $\begin{array}{l}- \\
13 \\
- \\
12 \\
- \\
- \\
32 \\
24 \\
-\end{array}$ & $\begin{array}{l}0 \\
7 \\
21 \\
12 \\
28 \\
- \\
0 \\
18 \\
-\end{array}$ & $\begin{array}{l}18(n=44)^{64} \\
11 \\
10 \\
- \\
- \\
- \\
- \\
- \\
-\end{array}$ & $\begin{array}{l}15 \\
0 \\
10 \\
0 \\
4 \\
- \\
11 \\
5 \\
17\end{array}$ & $\begin{array}{l}3 \\
20 \\
2 \\
6 \\
12 \\
5 \\
- \\
2 \\
6\end{array}$ & $\begin{array}{l}0 \\
7 \\
0 \\
0 \\
0 \\
- \\
0 \\
2 \\
0\end{array}$ \\
\hline $\begin{array}{l}\text { Artisan Aphakia } \\
\text { (Ophtec, } \\
\text { Groningen, The } \\
\text { Netherlands) }\end{array}$ & 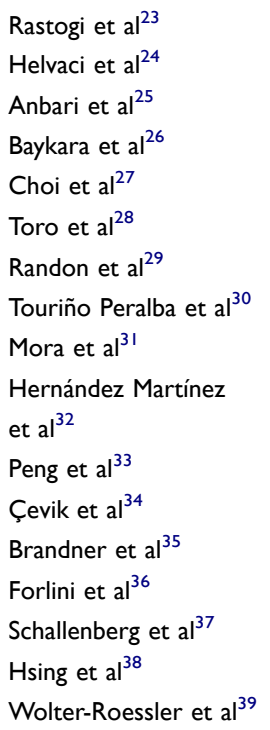 & $\begin{array}{l}14 \\
20 \\
16 \\
32 \\
103 \\
93 \\
31 \\
38 \\
32 \\
44 \\
\\
29 \\
30 \\
15 \\
320 \\
31 \\
34 \\
48\end{array}$ & $\begin{array}{l}6 \\
6 \\
24 \\
9 \\
24 \\
60 \\
29 \\
12 \text { (median) } \\
12 \\
33 \\
\\
6 \\
38 \\
14.9 \\
63.6 \\
25.2 \\
21.4 \\
14\end{array}$ & $\begin{array}{l}21 \\
10 \\
0 \\
13 \\
- \\
2 \\
- \\
8 \\
- \\
12^{\mathrm{a}} \\
- \\
0 \\
- \\
5 \\
32 \\
18 \\
-\end{array}$ & $\begin{array}{l}7 \\
25 \\
13 \\
19 \\
8 \\
23 \\
- \\
11 \\
22 \\
3^{\mathrm{a}} \\
\\
31 \\
0 \\
13 \\
2 \\
3 \\
0 \\
2\end{array}$ & $\begin{array}{l}1 \\
- \\
12 \\
- \\
24 \\
10 \\
- \\
9 \\
32 \\
4 \\
35 \\
- \\
- \\
3 \\
- \\
- \\
-\end{array}$ & $\begin{array}{l}0 \\
0 \\
0 \\
0 \\
4 \\
2 \\
6 \\
8 \\
25 \\
9^{\mathrm{a}} \\
- \\
0 \\
0 \\
1 \\
0 \\
0 \\
4\end{array}$ & $\begin{array}{l}7 \\
0 \\
0 \\
0 \\
10 \\
2 \\
10 \\
3 \\
0 \\
- \\
\\
7 \\
37 \\
7 \\
1 \\
0 \\
0 \\
4\end{array}$ & $\begin{array}{l}0 \\
0 \\
0 \\
0 \\
0 \\
1 \\
0 \\
3 \\
3 \\
1^{\mathrm{a}} \\
0 \\
10 \\
0 \\
0.3 \\
3 \\
0 \\
2\end{array}$ \\
\hline Artisan/Verisyse & $\begin{array}{l}\text { Choragiewicz et } \mathrm{al}^{40} \\
\text { Gonnermann et } \mathrm{al}^{41} \\
\text { Gonnermann et } \mathrm{al}^{42} \\
\text { Gonnermann et } \mathrm{al}{ }^{43} \\
\text { Gonnermann et } \mathrm{al}^{44} \\
\text { Rüfer et } \mathrm{al}{ }^{45}\end{array}$ & $\begin{array}{l}47 \\
137 \\
62 \\
13 \\
23 \\
22\end{array}$ & $\begin{array}{l}15.9 \\
5 \\
34 \\
37 \\
18 \\
17\end{array}$ & $\begin{array}{l}17 \\
25 \\
3 \\
8 \\
13 \\
-\end{array}$ & $\begin{array}{l}0 \\
4 \\
0 \\
0 \\
0 \\
5\end{array}$ & $\begin{array}{l}- \\
- \\
6 \\
6 \\
43 \\
-\end{array}$ & $\begin{array}{l}- \\
9 \\
6 \\
0 \\
4 \\
-\end{array}$ & $\begin{array}{l}- \\
9 \\
5 \\
0 \\
13 \\
9\end{array}$ & $\begin{array}{l}2 \\
0 \\
0 \\
8 \\
0 \\
0\end{array}$ \\
\hline $\begin{array}{l}\text { Excelens (Excel } \\
\text { Optics Pvt. Ltd., } \\
\text { Chennai, India) }\end{array}$ & $\begin{array}{l}\text { Jare et } \mathrm{al}^{46} \\
\text { Rao et } \mathrm{al}^{47} \\
\text { Mansoori et al } \\
\text { Kelkar et } \mathrm{al}^{49} \\
\text { Kelkar et } \mathrm{al}^{50} \\
\text { Jayamadhury et } \mathrm{al}^{51} \\
\text { Kavitha et } \mathrm{al}^{52} \\
\text { Patil et al }\end{array}$ & $\begin{array}{l}108 \\
30 \\
122 \\
90 \\
104 \\
61 \\
25 \\
15\end{array}$ & $\begin{array}{l}6 \\
6 \\
7.48 \\
12 \\
12 \\
12 \\
16 \\
12\end{array}$ & $\begin{array}{l}- \\
- \\
16 \\
20 \\
19 \\
10 \\
4 \\
-\end{array}$ & $\begin{array}{l}3 \\
0 \\
21 \\
8 \\
7 \\
0 \\
4 \\
-\end{array}$ & $\begin{array}{l}5 \\
9 \\
- \\
8 \\
11(n=90) \\
12 \\
- \\
-\end{array}$ & $\begin{array}{l}0 \\
0 \\
5 \\
2 \\
2 \\
11 \\
4 \\
13\end{array}$ & $\begin{array}{l}0 \\
- \\
7 \\
0 \\
0 \\
0 \\
4 \\
-\end{array}$ & $\begin{array}{l}0 \\
0 \\
2 \\
1 \\
1 \\
0 \\
0 \\
-\end{array}$ \\
\hline $\begin{array}{l}\text { Freedom } \\
\text { (Freedom } \\
\text { Ophthalmic Pvt. } \\
\text { Ltd., Hosur, } \\
\text { India) }\end{array}$ & Sumitha et $\mathrm{al}^{54}$ & 36 & 3 & 44 & 3 & - & 3 & 0 & 0 \\
\hline
\end{tabular}

(Continued) 
Table 3 (Continued).

\begin{tabular}{|l|l|l|l|l|l|l|l|l|l|}
\hline ICIOL & Authors & $\begin{array}{l}\text { Sample } \\
\text { Size }\end{array}$ & $\begin{array}{l}\text { Mean or } \\
\text { Median } \\
\text { Follow-Up } \\
\text { (Months) }\end{array}$ & $\begin{array}{l}\text { Pupil } \\
\text { Ovalization } \\
\text { (\%) }\end{array}$ & $\begin{array}{l}\text { Raised } \\
\text { IOP } \\
\text { (\%) }\end{array}$ & ECL (\%) & $\begin{array}{l}\text { CME } \\
\text { (\%) }\end{array}$ & $\begin{array}{l}\text { IOL } \\
\text { Disenclavation/ } \\
\text { Dislocation (\%) }\end{array}$ \\
\hline $\begin{array}{l}\text { Optima } \\
\text { (Rainbow } \\
\begin{array}{l}\text { Meditech LLC, } \\
\text { Chennai, India) }\end{array}\end{array}$ & Madhivanan et al ${ }^{55}$ & 48 & 12 & 16 & 10 & - & 4 & 0 \\
\hline $\begin{array}{l}\text { OV lens (Care } \\
\text { Group, India) }\end{array}$ & Ganesh et al (56 $^{56}$ & 100 & 13 & 34 & 8 & 11 & 8 & 5 \\
\hline
\end{tabular}

Notes: ${ }^{\text {a}}$ Reported together for both the prepupillary and retropupillary iris-claw lens groups.

Abbreviations: ICIOL, iris-claw intraocular lens; IOP, intraocular pressure; ECL, endothelial cell loss; CME, cystoid macular edema; RD, retinal detachment.

at 12 months follow-up. ${ }^{32}$ Choi et al showed that the ECL was not significant after 1 month postoperatively, signifying that the ECL was mainly due to factors related to surgery rather than the problem of ICIOL itself. ${ }^{27}$ Forlini et al observed no significant ECL after 5 years of followup. $^{36}$

\section{CME}

One of the major causes for a decrease in CDVA following cataract surgery is CME. ${ }^{6}$ As ICIOLs are often indicated in eyes secondary to complicated cataract surgery, the risk of CME should always be kept in mind. The frequency of $\mathrm{CME}$ following ICIOL implantation depends on the indication for surgery and ranges from $0 \%-25 \%{ }^{14-18,20-32,34-39,41-44,46-56}$ The duration of follow-up, sample size, and investigative method for CME in different studies also affect the CME rates. Use of OCT at regular follow-ups after cataract surgery might be useful in detecting non-clinical CME $(<20 / 40$ change in CDVA).$^{30}$ Dalby et al reported CME as the most common late complication in their clinical study with almost comparable rates in both IOL exchange (2 eyes) and IOL repositioning (2 eyes) groups at 2 years. ${ }^{14}$ Kristianslund et al found no statistically significant difference in the rate of CME (10\% versus $7 \%)$ or difference in central macular thickness $(+11 \mu \mathrm{m}$ versus $+10 \mu \mathrm{m})$ at 6 months follow-up, comparing retropupillary ICIOL implantation to the scleral repositioning of the IOL. ${ }^{16}$ Faria et al experienced CME in 5\% of cases and attributed it to the primary cause of the aphakia or the vitrectomy procedure itself. ${ }^{21}$ Touriño Peralba et al observed a higher incidence of CME in the prepupillary IOL group $(22 \%)$ than the retropupillary IOL group $(8 \%) .{ }^{30}$ Mora et al reported a cumulative 12-month incidence of $\mathrm{CME}$ in $25 \%$ of the cases after ICIOL implantation in aphakia, dislocated IOL and subluxated crystalline lenses. ${ }^{31}$ Hernández Martínez et al stated that diabetic patients had double the risk of developing CME than nondiabetic patients. ${ }^{32}$ Madhivanan et al found a higher incidence of CME in the scleral-fixated IOL group (12\%) than the ICIOL group (4\%) and stated that using triamcinolone-assisted vitrectomy in the ICIOL group might have reduced the CME rate. ${ }^{55}$

\section{Disenclavtion or Dislocation of the ICIOL}

The redislocation rates after retropupillary ICIOL implantation have been reported between $0 \%$ and $37 \%{ }^{14-19,21-31,33-39,41-46,48-52,54-56}$ Disenclavation can be due to insufficient or incorrect primary haptic enclavation, which usually occurs with inexperienced surgeons. ${ }^{16,70}$ The atrophy of the iris at enclavation sites can also lead to redislocation. ${ }^{30,70}$ The risk of redislocation tends to be more among young patients $(<55$ years of age) and those with a trauma history. ${ }^{15,34,43}$ Three randomized clinical trials by Dalby et al, Kristianslund et al, and Helvaci et al, involving patients $>55$ years of age, observed redislocation at a rate of $3 \%, 2 \%$, and $0 \%$, respectively. ${ }^{14,16,24}$ Shuaib et al reported a disenclavation rate of $20 \%$ (mean follow-up of 6 months), and Cevik et al experienced a disenclavation rate of $37 \%$ (mean follow-up of 38 months). ${ }^{15,34}$ However, these two studies with the highest dislocation rate reported in literature included children between 2 and 16 years of age, and had a small sample size. Two retrospective studies by Toro et al, and Forlini et al, with the longest follow-up periods of around 5 years, observed haptic disenclavation at a rate of $2 \%$ and $1 \%$, respectively. ${ }^{28,36}$ 
Patients with disenclavated or dislocated ICIOL should be examined thoroughly by a vitreoretinal specialist before surgery to plan the management mode. The disenclavated ICIOL can be re-enclavated without major challenges by an experienced surgeon. Usually, a small corneal or limbal incision superiorly and a side-port are sufficient for the manoeuvering. The ICIOL can be held using a fixation forceps with a cannula or sinskey hook behind the optic and bring the dislocated side of the ICIOL into the anterior chamber. Once the ICIOL is secured with the forceps, the haptics can be enclavated in a standard fashion. In the case of totally dislocated IOLs, microforceps can be used via the pars plana approach and enclavated similarly. The new enclavation should be preferably in naive iris tissue different from the previous site of enclavation, which might have suffered trauma. ${ }^{59}$

Even in cases of intact haptic enclavation, decentration of ICIOL may happen sometimes. Decentration of ICIOL has been reported at a frequency of up to $7 \% .{ }^{14,31,38,40,45}$ However, it does not need any intervention, provided the optic covers the visual axis. Rarely, retropupillary ICIOLs need to be explanted if there is significant decentration hampering the visual outcome of the patient or if the haptics have been broken and severely traumatized. For explantation, pupil dilatation is preferred. After fashioning a sclero-corneal tunnel superiorly and a paracentesis on the temporal side, the optic has to held with the fixation forceps, and the haptic enclavation can be released by applying gentle pressure on the iris fold using a thin spatula. In a few cases, the iris has to be approached from behind to release the enclavations. ${ }^{71}$

\section{Retinal Detachment}

The surgeon's experience and skill in handling the complications of vitreous disruption during surgery play a role in the ultimate risk of retinal detachment (RD). The rate of $\mathrm{RD}$ seems to be associated more with the preoperative status of the patients rather than the ICIOL implantation. Only three studies have reported an RD incidence of more than 5\% with retropupillary ICIOLs, all of which included paediatric cases and had a sample size $\leq 30$ eyes. ${ }^{15,34,43}$

Other infrequent complications reported in the literature include iris atrophy (up to 24\%), transient hypotony (up to $19 \%$ ), iritis (up to $17 \%$ ), bullous keratopathy (up to $16 \%$ ), pigment dispersion/precipitates (up to $13 \%$ ), wound leakage $(\leq 2 \%)$, hyphema $(\leq 2 \%)$, iridodonesis $(\leq 2 \%)$, and endophthalmitis $(\leq 2 \%){ }^{26,28,30,31,36-38,40,41,55}$

\section{Strengths of the Present Review}

In contrast to the existing literature reviews, the present review has included different types of ICIOLs, including global and Indian IOLs, whose outcomes have been reported in the literature. This exhaustive review also analyzed more number of publications on retropupillary ICIOLs, including the non-English articles and those of the paediatric age group, to reduce bias.

\section{Limitations in Literature}

One of the significant issues of assessing prior publications is the difficulty of determining the surgeon's skill and experience. More randomized controlled trials with handpicked surgeons, larger sample size, longer follow-up, and rigorous reporting may provide more meaningful results, although this would be challenging to accomplish.

\section{Ongoing Trials}

An industry-sponsored clinical trial, NCT01547429 (Artisan Aphakia Lens for the Correction of Aphakia [Secondary] in Adults), is currently studying the use of ICIOL for aphakia, where a posterior chamber IOL is not indicated. The study is estimated to be completed in $2021 .^{72}$

\section{Conclusion}

Retropupillary ICIOL implantation in eyes with inadequate capsular or zonular support is a safe, faster, and effective procedure with good functional outcomes and fewer complications. The primary prerequisite for ICIOL placement is an iris tissue with adequate support. The shift in the placement of ICIOLs from prepupillary to a more physiological retropupillary position and change in the optic design from biconvex to convex-concave have given better functional outcomes and improved safety. Compared to prepupillary ICIOL and ACIOL, the risk of ECL is lower with retropupillary ICIOL due to the position of the IOL away from the corneal endothelium. A peripheral iridectomy is not mandatory nowadays while implanting ICIOL, as a pupillary block does not happen with a convex-concave vaulted design. Fashioning a scleral tunnel incision for ICIOL implantation provided better refractive results and less endothelial damage than a large corneal incision. The disenclavation of ICIOL happens mainly due to incorrect primary haptic enclavation or atrophic iris at the site of enclavation, which can be easily re-enclavated with proper techniques. The chance of redislocation tends to be more among the 
paediatric age group and those with a trauma history. Surgeons should make a decision on the surgical technique that is best in their hands, based on their experience and skills, each patient's unique ocular status, and accessibility to essential operating room instruments, weighing all the potential risks and benefits.

\section{Acknowledgment}

The author thanks Sumitha CV for her assistance in the data collection of the manuscript.

\section{Disclosure}

The author reports no conflicts of interest for this work.

\section{References}

1. Bellamy JP, Queguiner F, Salamé N, Montard M. Implantation secondaire. Techniques et complications [Secondary intraocular lens implantation: methods and complications]. $J$ Fr Ophtalmol. 2000;23:73-80.

2. Weene LE. Flexible open-loop anterior chamber intraocular lens implants. Ophthalmology. 1993;100:1636-1639. doi:10.1016/S01616420(13)31445-6

3. Biro Z. Results and complications of secondary intraocular lens implantation. J Cataract Refract Surg. 1993;19:64-67. doi:10.1016/ S0886-3350(13)80284-2

4. Ellerton CR, Rattigan SM, Chapman FM, Chitkara DK, Smerdon DL. Secondary implantation of open-loop, flexible, anterior chamber intraocular lenses. J Cataract Refract Surg. 1996;22:951-954. doi:10.1016/S0886-3350(96)80197-0

5. Stark WJ, Gottsch JD, Goodman DF, Goodman GL, Pratzer K. Posterior chamber intraocular lens implantation in the absence of capsular support. Arch Ophthalmol. 1989;107:1078-1083. doi:10.10 01/archopht.1989.01070020140048

6. Brunette I, Stulting RD, Rinne JR, Waring JO, Gemmil M. Penetrating keratoplasty with anterior or posterior chamber intraocular lens implantation. Arch Ophthalmol. 1994;112:1311-1319. doi:10.1001/archopht.1994.01090220061024

7. McCluskey P, Harrisberg B. Long-term results using scleral fixated posterior chamber intraocular lenses. $J$ Cataract Refract Surg. 1994;20:34-39. doi:10.1016/S0886-3350(13)80040-5

8. Bellucci R, Pucci V, Morselli S, Bonomi L. Secondary implantation of angle-supported anterior chamber and scleral-fixated posterior chamber intraocular lenses. J Cataract Refract Surg. 1996; 22:247-252. doi:10.1016/S0886-3350(96)80227-6

9. Malta JB, Banitt M, Musch DC, Sugar A, Mian SI, Soong HK. Long-term outcome of combined penetrating keratoplasty with scleral-sutured posterior chamber intraocular lens implantation. Cornea. 2009;28:741-746. doi:10.1097/ICO.0b013e31819bc31f

10. Worst JG. Iris claw lens. $J$ Am Intraocul Implant Soc. 1980;6:166-167. doi:10.1016/S0146-2776(80)80016-4

11. Menezo JL, Cisneros AL, Rodriguez-Salvador V. Endothelial study of iris-claw phakic lens: four year follow-up. $J$ Cataract Refract Surg. 1998;24:1039-1049. doi:10.1016/S0886-3350(98)80096-5

12. Brasse K, Neuhann TH. Posterior chamber Verisyse lens implantation to correct aphakia without capsular support. Video J Cataract Refract Surg. 2004;20.

13. Menezo JL, Martinez MC, Cisneros AL. Iris-fixated Worst claw versus sulcus-fixated posterior chamber lenses in the absence of capsular support. J Cataract Refract Surg. 1996;22:1476-1484. doi:10.1016/S0886-3350(96)80151-9
14. Dalby M, Kristianslund O, Drolsum L. Long-term outcomes after surgery for late in-the-bag intraocular lens dislocation: a randomized clinical trial. Am J Ophthalmol. 2019;207:184-194. doi:10.1016/j. ajo.2019.05.030

15. Shuaib AM, El Sayed Y, Kamal A, El Sanabary Z, Elhilali H. Transscleral sutureless intraocular lens versus retropupillary iris-claw lens fixation for paediatric aphakia without capsular support: a randomized study. Acta Ophthalmol. 2019;97:e850-e859. doi:10.1111/aos.14090

16. Kristianslund $\mathrm{O}$, Råen M, Østern AE, Drolsum L. Late in-the-bag intraocular lens dislocation: a randomized clinical trial comparing lens repositioning and lens exchange. Ophthalmology. 2017;124:151-159. doi:10.1016/j.ophtha.2016.10.024

17. Fouda SM, Al Aswad MA, Ibrahim BM, Bori A, Mattout HK. Retropupillary iris-claw intraocular lens for the surgical correction of aphakia in cases with microspherophakia. Indian J Ophthalmol. 2016;64:884-887. doi:10.4103/0301-4738.198844

18. Woo JH, Arundhati A, Chee SP, et al. Endothelial keratoplasty with anterior chamber intraocular lens versus secondary posterior chamber intraocular lens. Br J Ophthalmol. 2020;bjophthalmol-2020-316711. doi:10.1136/bjophthalmol-2020-316711

19. Vounotrypidis E, Schuster I, Mackert MJ, Kook D, Priglinger S, Wolf A. Secondary intraocular lens implantation: a large retrospective analysis. Graefes Arch Clin Exp Ophthalmol. 2019;257:125-134. doi:10.1007/s00417-018-4178-3

20. Schmidt I, Langenbucher A, Eppig T, Seitz B. Mögliche Einflussfaktoren für die postoperative Visusprognose bei retroiridaler Irisklauenlinsenimplantation [Possible Influencing Factors for the Prediction of Postoperative Visual Acuity Gain after Retroiridal Iris Claw Lens Implantation]. Klin Monbl Augenheilkd. 2018;23 5:885-888. doi:10.1055/s-0043-123879

21. Faria MY, Ferreira NP, Pinto JM, et al. Retropupillary iris claw intraocular lens implantation in aphakia for dislocated intraocular lens. Int Med Case Rep J. 2016;9:261-265. doi:10.2147/IMCRJ. S116771

22. Saleh M, Heitz A, Bourcier T, et al. Sutureless intrascleral intraocular lens implantation after ocular trauma. $J$ Cataract Refract Surg. 2013;39:81-86. doi:10.1016/j.jcrs.2012.08.063

23. Rastogi A, Goray A, Thacker P, Kamlesh B. Assessment of the safety and efficacy of primary retropupillary fixation of iris-claw intraocular lenses in children with large lens subluxations. Int Ophthalmol. 2018;38:1985-1992. doi:10.1007/s10792-017-0688-y

24. Helvaci S, Demirduzen S, Oksuz H. Iris-claw intraocular lens implantation: anterior chamber versus retropupillary implantation. Indian J Ophthalmol. 2016;64:45-49. doi:10.4103/0301-4738.17 8139

25. Anbari A, Lake DB. Posteriorly enclavated iris claw intraocular lens for aphakia: long-term corneal endothelial safety study. Eur J Ophthalmol. 2015;25(3):208-213. doi:10.5301/ejo.5000527

26. Baykara M, Ozcetin H, Yilmaz S, Timuçin OB. Posterior iris fixation of the iris-claw intraocular lens implantation through a scleral tunnel incision. Am J Ophthalmol. 2007;144:586-591. doi:10.1016/j.ajo. 2007.06.009

27. Choi EY, Lee CH, Kang HG, et al. Long-term surgical outcomes of primary retropupillary iris claw intraocular lens implantation for the treatment of intraocular lens dislocation. Sci Rep. 2021;11:726. doi:10.1038/s41598-020-80292-3

28. Toro MD, Longo A, Avitabile T, et al. Five-year follow-up of secondary iris-claw intraocular lens implantation for the treatment of aphakia: anterior chamber versus retropupillary implantation. PLoS One. 2019;14:e214140. doi:10.1371/journal.pone.0214140

29. Randon M, Queromes P, Pierre-Kahn V. Résultats à long terme de la bascule posturale myopique après implantation d'un implant clippé postérieurement à l'iris [Long term postural myopic shift assessment after posterior iris-claw aphakic intraocular lens implantation]. $J \mathrm{Fr}$ Ophtalmol. 2019;42:968-973. doi:10.1016/j.jfo.2019.05.011 
30. Touriño Peralba R, Lamas-Francis D, Sarandeses-Diez T, MartínezPérez L, Rodríguez-Ares T. Iris-claw intraocular lens for aphakia: can location influence the final outcomes? J Cataract Refract Surg. 2018;44:818-826. doi:10.1016/j.jcrs.2018.05.010

31. Mora P, Calzetti G, Favilla S, et al. Comparative analysis of the safety and functional outcomes of anterior versus retropupillary iris-claw IOL fixation. $J$ Ophthalmol. 2018;2018:8463569. doi:10.1155/2018/8463569

32. Hernández Martínez A, Almeida González CV. Iris-claw intraocular lens implantation: efficiency and safety according to technique. $J$ Cataract Refract Surg. 2018;44:1186-1191. doi:10.1016/j. jcrs.2018.06.049

33. Peng RM, Guo YX, Qiu Y, Hao YS, Hong J. Complications and outcomes of descemet stripping automated endothelial keratoplasty with artisan aphakia intraocular lens implantation. Int $J$ Ophthalmol. 2018;11:607-611. doi:10.18240/ijo.2018.04.11

34. Çevik SG, Çevik MÖ, Özmen AT. Iris-claw intraocular lens implantation in children with ectopia lentis. Arq Bras Oftalmol. 2017;80:114-117. doi:10.5935/0004-2749.20170027

35. Brandner M, Thaler-Saliba S, Plainer S, Vidic B, El-Shabrawi Y, Ardjomand N. Retropupillary fixation of iris-claw intraocular lens for aphakic eyes in children. PLoS One. 2015;10:e126614. doi:10.1371/journal.pone.0126614

36. Forlini M, Soliman W, Bratu A, Rossini P, Cavallini GM, Forlini C. Long-term follow-up of retropupillary iris-claw intraocular lens implantation: a retrospective analysis. BMC Ophthalmol. 2015;15:143. doi:10.1186/s12886-015-0146-4

37. Schallenberg M, Dekowski D, Hahn A, Laube T, Steuhl KP, Meller D. Aphakia correction with retropupillary fixated iris-claw lens (Artisan) - long-term results. Clin Ophthalmol. 2014;8: 137-141. doi:10.2147/OPTH.S55205

38. Hsing YE, Lee GA. Retropupillary iris claw intraocular lens for aphakia. Clin Exp Ophthalmol. 2012;40:849-854. doi:10.1111/ j.1442-9071.2012.02808.x

39. Wolter-Roessler M, Küchle M. Ergebnisse der Aphakiekorrektur durch retroiridal fixierte Kunstlinse [Correction of aphakia with retroiridally fixated IOL]. Klin Monbl Augenheilkd. 2008;225:1041-1044. doi:10.1055/s-2008-1027721

40. Choragiewicz T, Rejdak R, Grzybowski A, et al. Outcomes of sutureless iris-claw lens implantation. J Ophthalmol. 2016;2016:7013709. doi:10.1155/2016/7013709

41. Gonnermann J, Klamann MK, Maier AK, et al. Visual outcome and complications after posterior iris-claw aphakic intraocular lens implantation. $J$ Cataract Refract Surg. 2012;38:2139-2143. doi:10.1016/j.jcrs.2012.07.035

42. Gonnermann J, Amiri S, Klamann M, et al. Endothelzellverlust nach retropupillar fixierter Irisklauen-Linse [Endothelial cell loss after retropupillary iris-claw intraocular lens implantation]. Klin Monbl Augenheilkd. 2014;231:784-787. doi:10.1055/s-00341368453

43. Gonnermann J, Torun N, Klamann MK, Maier AK, von Sonnleithner C, Bertelmann E. Posterior iris-claw aphakic intraocular lens implantation in subluxated lenses due to Marfan syndrome. Eur J Ophthalmol. 2014;24:352-357. doi:10.5301/ejo.5000366

44. Gonnermann J, Torun N, Klamann MK, et al. Visual outcomes and complications following posterior iris-claw aphakic intraocular lens implantation combined with penetrating keratoplasty. Graefes Arch Clin Exp Ophthalmol. 2013;251:1151-1156. doi:10.1007/s00417012-2226-y

45. Rüfer F, Saeger M, Nölle B, Roider J. Implantation of retropupillar iris claw lenses with and without combined penetrating keratoplasty. Graefes Arch Clin Exp Ophthalmol. 2009;247:457-462. doi:10.1007/ s00417-008-0940-2

46. Jare NM, Kesari AG, Gadkari SS, Deshpande MD. The posterior iris-claw lens outcome study: 6-month follow-up. Indian J Ophthalmol. 2016;64:878-883. doi:10.4103/0301-4738.198843
47. Rao R, Sasidharan A. Iris claw intraocular lens: a viable option in monocular surgical aphakia. Indian J Ophthalmol. 2013;61:74-75. doi:10.4103/0301-4738.107198

48. Mansoori T, Agraharam SG, Sannapuri S, Manwani S, Balakrishna N. Surgical outcomes of retropupillary-fixated iris-claw intraocular lens. J Curr Ophthalmol. 2020;32:149-153. doi:10.4103/ JOCO.JOCO_92_20

49. Kelkar AS, Kelkar JA, Kothari AA, Kelkar SB. Comparison of flanged intrascleral intraocular lens fixation versus iris claw intraocular lens fixation: a retrospective study. Indian $J$ Ophthalmol. 2019;67:1838-1842. doi:10.4103/ijo.IJO_300_19

50. Kelkar A, Shah R, Vasavda V, Kelkar J, Kelkar S. Primary iris claw IOL retrofixation with intravitreal triamcinolone acetonide in cases of inadequate capsular support. Int Ophthalmol. 2018;38:111-117. doi:10.1007/s10792-017-0467-9

51. Jayamadhury G, Potti S, Kumar KV, Kumar RM, Divyansh Mishra KC, Nambula SR. Retropupillary fixation of iris-claw lens in visual rehabilitation of aphakic eyes. Indian $J$ Ophthalmol. 2016;64:743-746. doi:10.4103/0301-4738.195012

52. Kavitha V, Balasubramanian P, Heralgi MM. Iris-claw versus posterior chamber fixation intraocular lens implantation in pediatric traumatic cataract. Taiwan J Ophthalmol. 2016;6:69-74. doi:10.1016/j. tjo.2016.04.001

53. Patil KB, Meleth P, Shanker MP. Pars plana vitrectomy with posterior iris claw implantation for posteriorly dislocated nucleus and intraocular lens. Indian J Ophthalmol. 2011;59:497-500. doi:10.4103/ 0301-4738.86321

54. Sumitha CV, Pai V, Thulasidas M. Retropupillary iris-claw intraocular lens implantation in aphakic patients. Indian $J$ Ophthalmol. 2020;68:597-602. doi:10.4103/ijo.IJO_1043_19

55. Madhivanan N, Sengupta S, Sindal M, Nivean PD, Kumar MA, Ariga M. Comparative analysis of retropupillary iris claw versus scleral-fixated intraocular lens in the management of post-cataract aphakia. Indian J Ophthalmol. 2019;67:59-63. doi:10.4103/ijo.IJO_326_18

56. Ganesh S, Brar S, Relekar K. Long term clinical and visual outcomes of retrofixated iris claw lenses implantation in complicated cases. Open Ophthalmol J. 2016;10:111-118. doi:10.2174/1874364101610010111

57. Drolsum L, Kristianslund O. Implantation of retropupillary iris-claw lenses: a review on surgical management and outcomes. Acta Ophthalmol. 2021. doi:10.1111/aos.14824

58. Mikropoulos DG, Kymionis GD, Grentzelos MA, Voulgari N, Katsanos A, Konstas AG. Combined pupilloplasty and retropupillary iris-claw intraocular lens implantation with DSAEK in a patient with traumatic iridoplegia, aphakia and corneal decompensation. Ophthalmol Ther. 2019;8:497-500. doi:10.1007/s40123-019-0198-2

59. Apple DJ, Mamalis N, Loftfield K, et al. Complications of intraocular lenses. A historical and histopathological review. Surv Ophthalmol. 1984;29:1-54.

60. Mamalis N. Explantation of intraocular lenses. Curr Opin Ophthalmol. 2000;11:289-295. doi:10.1097/00055735-200008000-00011

61. Mohr A, Hengerer F, Eckardt C. Retropupillare Fixation der Irisklauenlinse bei Aphakie. Einjahresergebnisse einer neuen Implantationstechnik [Retropupillary fixation of the iris claw lens in aphakia. 1 year outcome of a new implantation techniques]. Ophthalmologe. 2002;99:580-583. doi:10.1007/s00347-001-0563-z

62. McDonnell PJ, Taban M, Sarayba M, et al. Dynamic morphology of clear corneal cataract incisions. Ophthalmology. 2003;110:2342-2348. doi:10.1016/S0161-6420(03)00733-4

63. Taban M, Behrens A, Newcomb RL, et al. Acute endophthalmitis following cataract surgery: a systematic review of the literature. Arch Ophthalmol. 2005;123:613-620. doi:10.1001/archopht.123.5.613

64. Dalby M, Kristianslund O, Østern AE, Falk RS, Drolsum L. Longitudinal corneal endothelial cell loss after corrective surgery for late in-the-bag IOL dislocation: a randomized clinical trial. $J$ Cataract Refract Surg. 2020;46:1030-1036. doi:10.1097/j. jcrs.0000000000000213 
65. De Silva SR, Arun K, Anandan M, Glover N, Patel CK, Rosen P. Irisclaw intraocular lenses to correct aphakia in the absence of capsule support. J Cataract Refract Surg. 2011;37:1667-1672. doi:10.1016/j. jcrs.2011.03.051

66. Güell JL, Verdaguer P, Elies D, et al. Secondary iris-claw anterior chamber lens implantation in patients with aphakia without capsular support. Br J Ophthalmol. 2014;98:658-663. doi:10.1136/bjophthalmol-2013-304035

67. Gawdat GI, Taher SG, Salama MM, Ali AA. Evaluation of Artisan aphakic intraocular lens in cases of pediatric aphakia with insufficient capsular support. $J$ AAPOS. 2015;19:242-246. doi:10.1016/j. jaapos.2015.03.014

68. Chen Y, Liu Q, Xue C, Huang Z, Chen Y. Three-year follow-up of secondary anterior iris fixation of an aphakic intraocular lens to correct aphakia. J Cataract Refract Surg. 2012;38:1595-1601. doi:10.1016/j.jcrs.2012.04.037
69. Drolsum L, Haaskjold E. Causes of decreased visual acuity after cataract extraction. J Cataract Refract Surg. 1995;21:59-63. doi:10.1016/S0886-3350(13)80481-6

70. Kim MS, Park SJ, Joo K, Kang HG, Kim M, Woo SJ. Single-haptic dislocation of retropupillary iris-claw intraocular lens: outcomes of reenclavation. Ophthalmic Surg Lasers Imaging Retina. 2020;51:384-390. doi:10.3928/23258160-20200702-03

71. Brockmann T, Gonnermann J, Brockmann C, Torun N, Joussen AM, Bertelmann E. Morphologic alterations on posterior iris-claw intraocular lenses after traumatic disenclavation. $\mathrm{Br} J$ Ophthalmol. 2014;98:1303-1307. doi:10.1136/bjophthalmol-2014-305364

72. Shen JF, Deng S, Hammersmith KM, et al. Intraocular lens implantation in the absence of zonular support: an outcomes and safety update: a report by the American Academy of Ophthalmology. Ophthalmology. 2020;127:1234-1258. doi:10.1016/j.ophtha.2020. 03.005
Clinical Ophthalmology

\section{Publish your work in this journal}

Clinical Ophthalmology is an international, peer-reviewed journal covering all subspecialties within ophthalmology. Key topics include: Optometry; Visual science; Pharmacology and drug therapy in eye diseases; Basic Sciences; Primary and Secondary eye care; Patient Safety and Quality of Care Improvements. This journal is indexed on PubMed

Submit your manuscript here: https://www.dovepress.com/clinical-ophthalmology-journal
Dovepress

Central and CAS, and is the official journal of The Society of Clinical Ophthalmology (SCO). The manuscript management system is completely online and includes a very quick and fair peer-review system, which is all easy to use. Visit http://www.dovepress.com/ testimonials.php to read real quotes from published authors. 